\title{
Water and soil quality in an Otago deer farm
}

\author{
R.W. McDOWELL and R.J. PATON \\ AgResearch, Invermay Agricultural Centre, PB 50034, Mosgiel \\ richard.mcdowell@agresearch.co.nz
}

\begin{abstract}
This paper outlines findings for three experiments on the AgResearch Invermay deer farm that quantified soil and water quality via fence-line pacing and wallowing, and water quality in streams draining the farm. Five weeks after winter grazing (28 hinds/ha), fence-line pacing decreased soil macroporosity and saturated hydraulic conductivity, and increased suspended sediment (SS; $0.226 \mathrm{~g} / 100 \mathrm{ml}$ ), total phosphorus (P) (TP; $2.0 \mathrm{mg} / 1$ ), mainly as particulate $\mathrm{P}$ (up to $90 \%$ of TP), and E. coli (3.52 $\left.\log _{10} \mathrm{cfu} / 100 \mathrm{ml}\right)$ concentrations in a simulated overland flow 1 day after grazing had stopped compared to soils from the rest of the paddock $(0.148 \mathrm{~g} / 100 \mathrm{ml}$, $0.86 \mathrm{mg} / 1$ and $\left.2.86 \log _{10} / 100 \mathrm{ml}\right)$. Six weeks following a first simulated rainfall event, and without interim grazing, concentrations in the second simulated event had decreased but losses of $\mathrm{P}$, especially in fence-line paced soils, were still high and above recommended limits for surface water quality (TP $=0.033 \mathrm{mg} / \mathrm{l})$. A survey of visible erosion in 6 deer paddocks with topography (2$10^{\circ}$ ) yielded a mean erosion rate of $1.08 \mathrm{t} / \mathrm{ha} / \mathrm{yr}$ (range, 0.41-2.01 t/ha/yr), $43 \%$ associated with fence-lines, troughs or gateways and $57 \%$ associated with wallows. Data from three waterways indicated that mean values for two sites that drain $100 \%$ deer farmed land, exceeded current lowland surface water limits for dissolved $(0.01$ $\mathrm{mg} / \mathrm{l})$ and TP $(0.033 \mathrm{mg} / \mathrm{l})$ and ammoniacal-nitrogen $(\mathrm{N})$ $(0.021 \mathrm{mg} \mathrm{N} / 1)$. Limits for E. coli $(126$ E. coli $/ 100 \mathrm{ml})$ and nitrate-N (0.444 mg N/l) were also exceeded at another site, which drained a wallow. All guideline values were exceeded during storm flow when ephemeral streams, commonly draining wallows, were flowing to permanent waterways. However, loads of P, N and SS were below average for mixed-grazing pasture catchments in New Zealand. This was attributed to a dry year (rainfall $<20 \%$ of normal), which suggests management targeting fence-line pacing and wallowing should mitigate bad effects on water quality from deer farmed catchments in average or wet years.
\end{abstract}

Keywords: E. coli, nitrogen, nutrient load, phosphorus, suspended sediment

\section{Introduction}

Numbers of red deer (Cervus elaphus) and their hybrids with wapiti (Cervus elaphus spp.) farmed in New Zealand have risen from c. 1.5 million in 1997 to an estimated 2.5 million in 2003 (Loza 2003). With intensification comes concern that water and soil quality may deteriorate, and risk sustainability (Moyes 2002). Some evidence has indicated that much erosion can occur from fields with deer or elk (Evans 1996; Thorrold \& Trolove 1996) and that the concentrations of thermo-tolerant Campylobacter and Eschericha coli (E. coli) downstream of deer farms are high (Eyles et al. 2002). Some behavioural characteristics, such as fence-line pacing and wallowing appear, visually, to exacerbate these problems (e.g., erosion, Evans 1996; Pollard \& Drewry 2002; McDowell et al. 2004). Besides this data, little else is known about the effect of deer farming on water and soil quality.

Given the gap in knowledge, this paper outlines results from three studies on the AgResearch Invermay Deer farm. The first compared the potential for contaminant losses (phosphorus $(\mathrm{P})$, sediment, nitrogen $(\mathrm{N})$ species (ammonia, $\mathrm{NH}_{4}^{+}-\mathrm{N}$ and nitrate, $\mathrm{NO}_{3}^{-}-\mathrm{N}$ ) and E. coli) in overland flow via rainfall simulation from, and soil compaction in, a soil used for deer farming with and without fence-line pacing. The second study estimated erosion losses from a randomly selected subset of deer paddocks within the farm. Finally, the third experiment determined contaminant concentrations for wallows flowing to waterways during 2 storm events and concentrations and loads for 3 waterways draining the farm (site 1 that drains 180 ha, $90 \%$ deer farmed, 10\% forestry; site 2 that drains a 2 ha wallow; site 3 that drains 300 ha including site $\mathrm{B}$, and $60 \%$ other land equally split between sheep and forestry).

\section{Materials and methods}

Site

The AgResearch Invermay deer farm near Mosgiel covers $c .160$ ha split amongst 90 paddocks of rolling to steeper hill country at an altitude of 150 to $300 \mathrm{~m}$. The farm has been running since 1972, while about half has only been farmed with deer since 1991. Mean annual rainfall is $687 \mathrm{~mm}$ falling on 153 days of the year. The predominant soil type is a Warepa silt loam (mottled fragic Pallic soil) with outcrops of Cargill hill soils (acidic mafic Brown soil) higher up. Currently c. 1200 deer are farmed with a pasture rotation of 21-56 days depending on the time of year.

\section{Fence-line pacing study}

A paddock (about 1 ha) was selected where 8 plots $(2 \times$ $2 \mathrm{~m}$ ) were marked out at random, but a minimum of $2 \mathrm{~m}$ 
from the fence-line. Another 8 plots were randomly sited within $2 \mathrm{~m}$ of the fence-line. Twenty-eight hinds grazed the pasture for 5 weeks during June and July 2003. After grazing, the visually determined percentage of bare ground was c. $90 \%$ between 0 and $0.5 \mathrm{~m}$ away from the fence and c. $60 \%$ greater than $0.5 \mathrm{~m}$ away from the fence. One day after grazing had ceased, intact pasture soils were sampled from each plot using a metal cutting blade and soils placed in boxes, $1 \mathrm{~m}$ long by $20 \mathrm{~cm}$ wide by $12.5 \mathrm{~cm}$ deep. Soil boxes were then moved to an indoor rainfall simulation facility, inclined at $5 \%$ slope and rain applied at $17 \mathrm{~mm} / \mathrm{h}$ until overland flow was generated (0.6-23 minutes). Samples of flow (21) were collected and analyzed for suspended sediment (SS), $\mathrm{NH}_{4}^{+}-\mathrm{N}, \mathrm{NO}_{3}^{-}{ }^{-} \mathrm{N}$, E. coli, dissolved (filtered $<0.45 \mu \mathrm{m}$ ) reactive $\mathrm{P}$ (DRP), and total dissolved $\mathrm{P}$ (TDP) and total $\mathrm{P}$ (TP) after persulphate digestion. Particulate P (PP) was determined as the difference between TP and TDP. Soils were placed back in the paddock and re-sampled six weeks later for an additional simulated rainfall event. At the same time as sampling intact soils, cores were taken for determination of Olsen P, macroporosity ( $\%$ of pores $>30 \mu \mathrm{m})$, saturated hydraulic conductivity $\left(K_{\text {sat }}\right)$ and bulk density.

\section{Erosion study}

Six paddocks were selected to cover a range of slopes $\left(2-10^{\circ}\right)$. Five of the paddocks had been farmed with deer since 1991 when pasture was re-sown. One other paddock was also selected that had been farmed with deer since 1972. All paddocks were stocked with sheep prior to conversion to deer. Within each paddock erosion was noted as where bare ground was $>90 \%$ and topsoil $2.5 \mathrm{~cm}$ below adjacent un-eroded pasture (Thorrold \& Trolove 1996). This represents a compromise between underestimating non-visible erosion from the whole paddock, and over-estimating erosion in depressions due to soil compaction not loss. The depth, width and length was noted six times in the area and used to calculate the volume of soil lost. Erosion was classified as either associated with gateways and fence-lines or around troughs and wallows (including those associated with waterways).

\section{Catchment - waterway study}

Water samples were taken fortnightly for one year from the outlet of three catchments (sites 1-3) on the deer farm (Figure 1). These were analyzed for $\mathrm{SS}, \mathrm{NH}_{4}^{+}-\mathrm{N}_{2} \mathrm{NO}_{3}{ }^{-}$ -N, E. coli, DRP, TDP and TP. Characteristics of each catchment are given in Table 1. Flow from the outlet of catchment 3 was measured at a permanent level recorder, while a current meter and regression techniques used to estimate flows for catchment $1\left(\mathrm{r}^{2}=0.97\right)$. Loads of nutrients, sediment and $E$. coli were calculated via interpolation techniques (Robertson \& Roerish 1999). However, due to the small and flashy (sudden large events) nature of flow at catchment 2, loads were only estimated using instantaneous flow recordings. As such, some error is likely in calculating a specific yield.

In addition to regular sampling, two samplings were made of waterways flowing from deer paddocks during storm events in late winter. These waterways were ephemeral, generally associated with wallows, and only connected with waterways during storm events. Samples were analyzed for the same constituents as above.

\section{Results}

\section{Fence-line pacing study}

Macroporosity (a measure of soil pores $>30 \mu \mathrm{m}$, indicates no impairment of pasture growth if $>10 \%$, Drewry et al. 2002), bulk density and $K_{\text {sat }}$ values were less in the fenceline soils compared to soils from the rest of the paddock (Table 1). Soil physical properties improved 6 weeks after grazing, but differences still occurred between soils.

Concentrations of soil Olsen P were significantly greater in the fence-line soil $(53 \mathrm{mg} / \mathrm{kg})$ than in the rest of the paddock ( $34 \mathrm{mg} / \mathrm{kg})$, presumably due to greater dung deposition in the fence-line soil. For $\mathrm{P}$ in flow, the dominant fraction was PP followed by DRP. As P is associated with particulates $>0.45 \mu \mathrm{m}$, it is not surprising that $\mathrm{P}$ loss mirrored SS loss. However, 1 day after grazing no significant difference in $\mathrm{NH}_{4}^{+}-\mathrm{N}$ concentrations was noted between soils. Concentrations of $\mathrm{NO}_{3}^{-}-\mathrm{N}$ were greater in fence-line than soils from the rest of the paddock, but this difference disappeared 6 weeks later. Numbers of $E$. coli in flow were significantly different between soils 1 day after, but not 6 weeks after grazing had finished. Little or no decrease was noted for SS concentrations in flow 6 weeks after grazing compared to 1 day after grazing had finished.

\section{Erosion study}

Data for mean estimated annual erosion in each paddock is given in Table 2. The maximum total erosion was for paddock 4 with $24 \mathrm{t} / \mathrm{h}$ a for 12 years since this paddock had been re-sown into pasture and farmed with deer. The minimum total erosion was evident in paddock 1 with 5 t/ha over a 12 year period since deer farming had begun. The distribution of erosion was not significantly different between fence-line or gateway erosion and wallow or trough erosion ( $\mathrm{t}$-test, $\mathrm{P}=0.5$ ). Estimates of erosion are likely to be less than that occurring as erosion was only measured from areas $>90 \%$ bare ground and $>2.5 \mathrm{~cm}$ depth of topsoil missing. Erosion arising via overland flow from other areas is not accounted for.

\section{Catchment and waterway study}

Summary data for water quality parameters for each 
Figure 1 Catchment sampling sites, areas and locations, along with the location of paddocks used for erosion estimations.

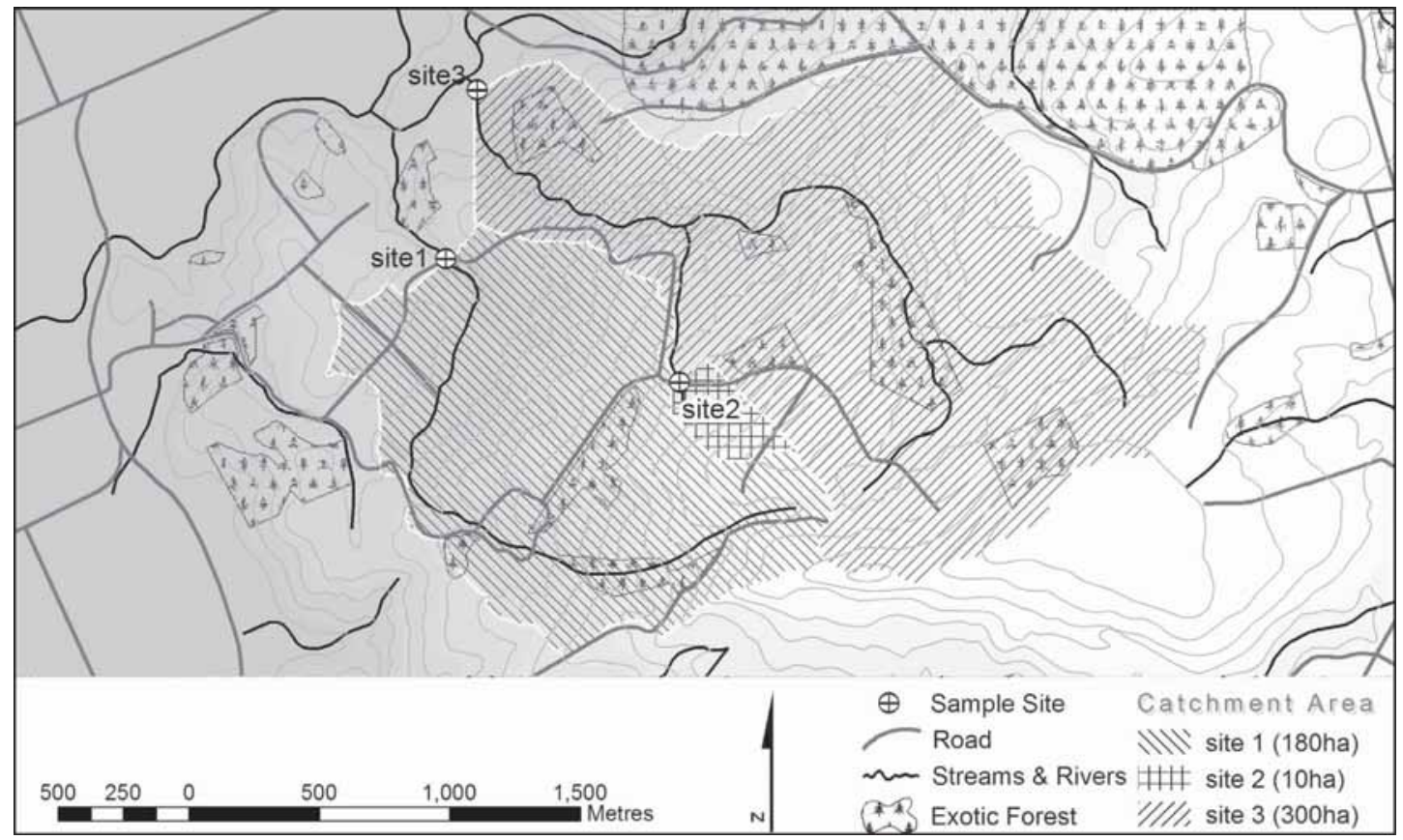

Table 1 Means for soil hydrologica- and physiochemical parameters and concentrations of contaminants in overland flow 1 day and 6 weeks after grazing by deer. LSD is the least significant difference between treatments at the $5 \%$ level.

\begin{tabular}{|c|c|c|c|}
\hline Parameter & Fence-line & Rest of paddock & LSD \\
\hline \multicolumn{4}{|l|}{1 day after grazing } \\
\hline Bulk density $\left(\mathrm{t} / \mathrm{m}^{3}\right)$ & 1.06 & 0.91 & 0.03 \\
\hline Macroporosity (\% v/v) & 6.8 & 16.1 & 1.8 \\
\hline$K_{\text {sat }}(\mathrm{mm} / \mathrm{h})$ & 58 & 692 & 381 \\
\hline DRP (mg/l) & 0.25 & 0.30 & 0.11 \\
\hline $\mathrm{PP}(\mathrm{mg} / \mathrm{l})$ & 1.68 & 0.45 & 0.63 \\
\hline $\mathrm{TP}(\mathrm{mg} / \mathrm{l})$ & 2.02 & 0.86 & 0.59 \\
\hline $\mathrm{SS}(\mathrm{g} / 100 \mathrm{ml})$ & 0.23 & 0.15 & 0.04 \\
\hline $\mathrm{NH}_{4}^{+}-\mathrm{N}(\mathrm{mg} / \mathrm{l})$ & 1.98 & 1.95 & 0.67 \\
\hline $\mathrm{NO}_{3}^{-}-\mathrm{N}(\mathrm{mg} / \mathrm{l})$ & 0.88 & 0.51 & 0.33 \\
\hline E. coli $\left(\log _{10}\right.$ cfu $\left.100 / \mathrm{ml}\right)$ & 3.52 & 2.86 & 0.65 \\
\hline \multicolumn{4}{|l|}{6 weeks after grazing } \\
\hline Bulk density $\left(\mathrm{t} / \mathrm{m}^{3}\right)$ & 1.10 & 0.94 & 0.06 \\
\hline Macroporosity (\% v/v) & 8.4 & 18.9 & 3.3 \\
\hline$K_{\text {sat }}(\mathrm{mm} / \mathrm{h})$ & 27 & 281 & 267 \\
\hline DRP (mg/l) & 0.11 & 0.12 & 0.03 \\
\hline $\mathrm{PP}(\mathrm{mg} / \mathrm{l})$ & 1.18 & 0.34 & 0.33 \\
\hline $\mathrm{TP}(\mathrm{mg} / \mathrm{l})$ & 1.31 & 0.50 & 0.32 \\
\hline $\mathrm{SS}(\mathrm{g} / 100 \mathrm{ml})$ & 0.22 & 0.14 & 0.04 \\
\hline $\mathrm{NH}_{4}^{+}-\mathrm{N}(\mathrm{mg} / \mathrm{l})$ & 0.05 & 0.03 & 0.02 \\
\hline $\mathrm{NO}_{3}^{-}-\mathrm{N}(\mathrm{mg} / \mathrm{l})$ & 1.29 & 1.27 & 0.37 \\
\hline E. coli $\left(\log _{10}\right.$ cfu $\left.100 / \mathrm{ml}\right)$ & 2.26 & 2.31 & 0.57 \\
\hline
\end{tabular}


Table 2 Annual estimated (until 2003) erosion from selected deer paddocks.

\begin{tabular}{lccc}
\hline Paddock & $\begin{array}{c}\text { Date deer } \\
\text { farming began }\end{array}$ & $\begin{array}{c}\text { Fence-line/gateway erosion } \\
(\mathrm{t} / \mathrm{ha} / \mathrm{yr})\end{array}$ & $\begin{array}{c}\text { Wallow/trough erosion } \\
(\mathrm{t} / \mathrm{ha} / \mathrm{yr})\end{array}$ \\
\hline 1 & 1991 & 0.29 & 0.12 \\
2 & 1991 & 0.22 & 0.66 \\
3 & 1991 & 0.10 & 0.86 \\
4 & 1991 & 0.98 & 1.04 \\
5 & 1991 & 0.93 & 0.28 \\
6 & 1972 & 0.11 & 0.28 \\
Mean (\%) & & $0.44(45)$ & $0.54(55)$ \\
\hline
\end{tabular}

Table 3 Catchment area-specific loads (all units $\mathrm{kg} / \mathrm{ha} / \mathrm{yr}$ except E. coli, $\log _{10}$ cfu/ha/yr) of nutrients, sediment and $E$. coli in each of the study catchments.

\begin{tabular}{|c|c|c|c|c|}
\hline \multirow{2}{*}{ Parameter } & \multicolumn{3}{|c|}{- Catchment } & \multirow{2}{*}{$\begin{array}{l}\text { Range for } \\
\text { NZ studies }\end{array}$} \\
\hline & 1 & 2 & 3 & \\
\hline DRP & 0.03 & 0.01 & 0.01 & $0.04-0.30$ \\
\hline DOP & 0.05 & 0.02 & 0.02 & - \\
\hline TDP & 0.05 & 0.03 & 0.03 & - \\
\hline PP & 0.09 & 0.43 & 0.07 & - \\
\hline TP & 0.14 & 0.46 & 0.10 & $0.3-1.7$ \\
\hline SS & 133 & 621 & 97 & $600-2000$ \\
\hline E. coli & 8.90 & 10.45 & 8.56 & - \\
\hline $\mathrm{NH}_{4}{ }^{-} \mathrm{N}$ & 0.05 & 0.60 & 0.08 & $0-0.3$ \\
\hline $\mathrm{NO}_{3}^{4}-\mathrm{N}$ & 0.65 & 0.45 & 0.68 & $1-5$ \\
\hline
\end{tabular}

${ }^{1}$ Taken from Wilcock (1986) and Vant (2001).

sampling site is given in Figure 2 while annual loads are given in Table 3. The median concentration of E. coli exceeded the water quality guideline for contact recreation (2.10 $\log _{10} \mathrm{cfu} / 100 \mathrm{ml}$, MfE 1999) at site 2, but not at site 1 or 3 . In contrast, the median values for nitrate-N and DRP were below those likely to yield adverse effects on lowland streams in slightly disturbed ecosystems (0.444 $\mathrm{mg} \mathrm{NO}_{3}^{-}-\mathrm{N} / 1$ and $0.01 \mathrm{mg} \mathrm{P} / 1$, ANZECC 2000). However, median values for TP at all sites were greater than the recommended limits for lowland streams $(0.033$ mg P/1, ANZECC 2000), while median $\mathrm{NH}_{4}{ }^{+}-\mathrm{N}$ concentrations exceeded guidelines $\left(0.021 \mathrm{mg} \mathrm{NH}_{4}^{+}-\mathrm{N} /\right.$ 1, ANZECC 2000) at sites 1 and 2, but not at site 3. In contrast to the regular sampling regime, median values for ephemeral waterways connected the main stream during storm flow were greater $(\mathrm{DRP}=0.02 \mathrm{mg} / 1, \mathrm{TP}=$ $0.25 \mathrm{mg} / 1, \mathrm{NH}_{4}^{+}-\mathrm{N}=0.28 \mathrm{mg} / 1, \mathrm{NO}_{3}^{-}-\mathrm{N}=1.00 \mathrm{mg} / 1, E$. coli $=2.12 \log _{10} \mathrm{cfu} / 100 \mathrm{ml}$ ). Compared to a range of values for catchments in pastoral agriculture (Table 3), loads of most water quality parameters for each catchment were less than the mean load noted for a range of catchments in pasture in New Zealand (Wilcock 1986; Vant 2001).

\section{Discussion}

For the fence-line pacing study, concentrations of SS were greater than those found in overland flow from cattle grazed pasture plots in the Waikato (0.036-0.081 $\mathrm{g} / 100 \mathrm{ml}$ ), despite flow being produced at a higher rainfall intensity of 40-55 mm/hr (Nguyen et al. 1998). To some degree this can be attributed to stocking rate but also differences in soil type, Pallic soils are erosion prone while Brown and Granular soils in the Waikato are less so. At the other end of the scale, Thorrold \& Trolove (1996) noted very high erosion rates (2.1-22 t/ha/yr) in paddocks on a Bay of Plenty deer farm. Although the farm was located on very erosion prone Pumice soils, the median slope in their study was more than double that of ours $\left(5^{\circ}\right)$.

Naturally, soil that is bare of grass, such as in fenceline paced areas, is more prone to SS loss than soil with good pasture cover where soil is bound together by roots, and shoots filter out SS in overland flow. Fence-line pacing also decreases infiltration rates as the soil becomes compacted (Table 1) promoting water to flow over the soil surface. Consequently, similar to Thorrold \& Trolove (1996) a large proportion of total visible erosion in our study was associated with fence-line pacing (Table 2). Fence-line pacing can be evident over large stretches of deer grazed land and is therefore a large potential source for SS loss and topsoil loss. For instance Evans (1996) noted that c. $38 \%$ of land along a $26 \mathrm{~km}$ long fence-line was judged as severely or very severely damaged during summer grazing by Reindeer in Norway. However, SS loss from fence-line paced soil alone will underestimate total soil loss as areas with good pasture cover (see Table 1) also contribute to SS loss.

Since P is strongly bound to the topsoil much P loss 
Figure 2 Box plots of E. coli, suspended sediment, DRP, TP, ammonical-N and nitrate-N for three regularly sampled waterways draining the Invermay deer farm. Upper and lower boundaries indicate the 25th and 75th percentiles, the line within box is the median, the whiskers are the 10th and 90th percentile, and the circles, outliers.

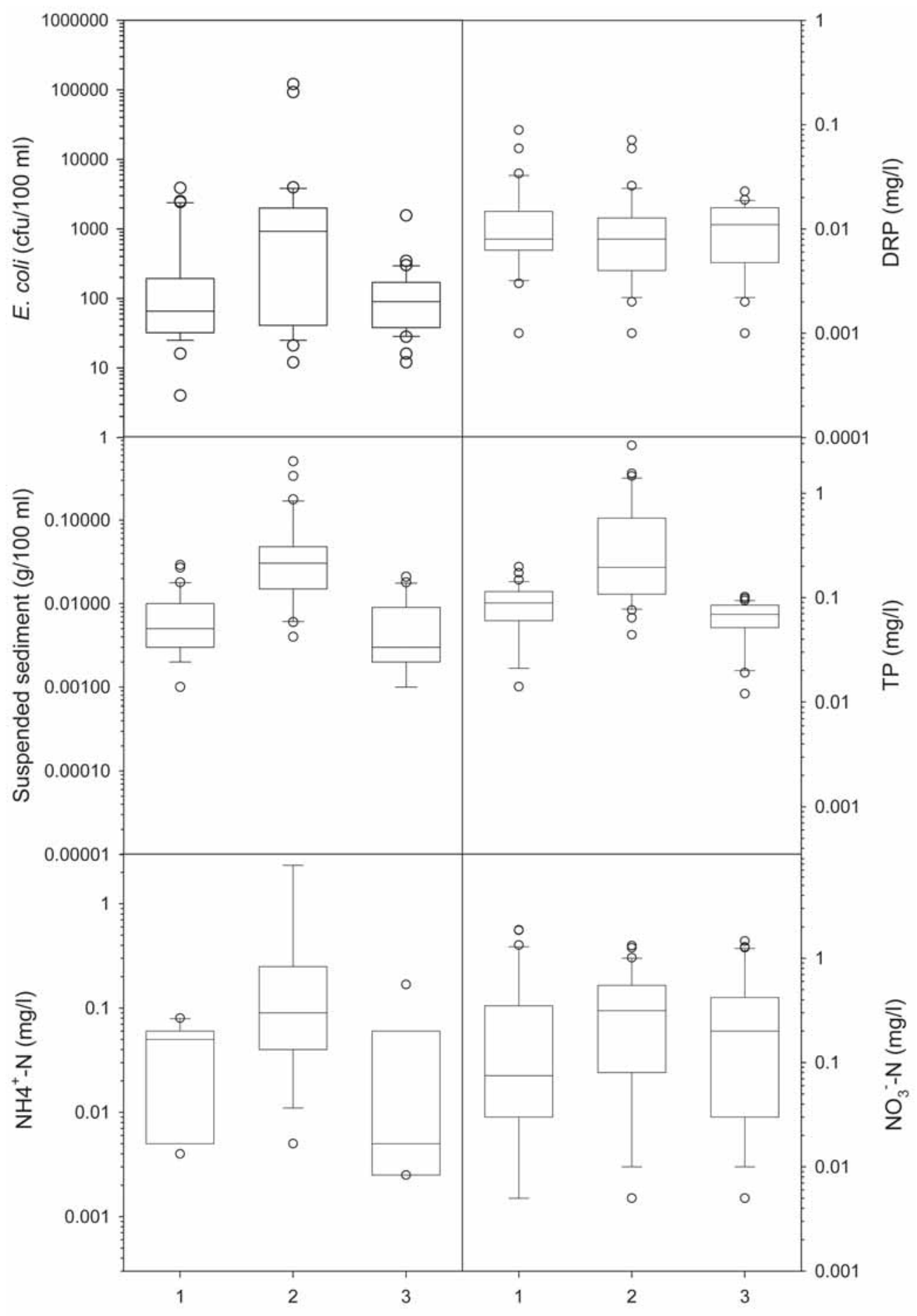


can occur via SS loss. This is clearly evident in all the studies, especially in areas where the soil is disturbed, such as water in ephemeral channels during storm flow from wallowing areas, and overland flow from fenceline paced soils (Tables 1 and 2, and Figure 2). Wallowing areas, and indeed anywhere where deer spend more of their time, are areas where much urine and faecal deposition occurs. In addition to a source of nutrients $(\mathrm{N}$ and $\mathrm{P}$ ), there is also a high potential for $E$. coli transfer. This is clearly evident in both the very high $E$. coli concentrations from water in ephemeral streams from wallows, but also in the second catchment sampling site, downstream of a wallow, and in fence-line pacing study. Other studies such as those of Davies-Colley \& Nagels (2002) have also found elevated E. coli downstream of deer activity. The interesting point is that, while the concentration of $E$. coli decreases with time if no more faecal deposition occurs, concentrations were still high enough to be of concern in fence-line paced soils 6 weeks after grazing had stopped. Similarly, the concentrations of $E$. coli in the second catchment were rarely below acceptable limits. Similarly, concentrations of N species were elevated in areas where deer congregated, but decreased with time.

While concentrations of $\mathrm{P}, \mathrm{SS}$ and $E$. coli were of concern during regular catchment samplings, these elevated concentrations may in part have been due to the low quantity of overall runoff. Although a direct relationship between precipitation and runoff is not guaranteed, precipitation during the sampling year was only three-quarters of usual and overall runoff likely to be much less than an average or wet year. While dilution of conserved species such as nitrate will occur, loss of $\mathrm{P}$, $\mathrm{SS}$ and E. coli tend to increase with overland flow. Hence, loads presented in Table 3 are unrepresentative, and much less than in a normal year.

This study highlights the need for additional work in establishing loads of contaminant losses from deer farmed land. While concentrations of sediment, $\mathrm{P}$ and $E$. coli in some events from either natural or simulated rainfall highlight potential for impaired water quality as a result of wallowing and fence-line pacing, the overall impact on a catchment scale over a year (i.e. load estimates) is unclear due to irregular rainfall. The data shows that management should be directed towards minimising fence-line pacing and the promotion of wallowing areas not connected to waterways in order to prevent contaminant loss and maintain water and soil quality.

\section{ACKNOWLEDGEMENTS}

Funding for this work was provided by the New Zealand Foundation for Research, Science and Technology under contracts AGRX002 and C10X0202.

\section{REFERENCES}

ANZECC 2000. Australian and New Zealand Guidelines for fresh and Marine Water Quality. Volumes 1 and 2. Canberra, ACT, Australia. Australian and New Zealand Environment and Conservation Council.

Davies-Colley, R. J.; Nagels, J. W. 2002. Effects of dairying on water quality of lowland streams in Westland and Waikato. Proceedings of the New Zealand Grassland Association 64: 107-114.

Drewry, J. J.; Littlejohn, R. P.; Paton, R. J.; Singleton, P. L.; Boyes, M.; Judge, A.; Monaghan, R. M.; Smith, L. C. 2002. Dairy pasture yield responses to macroporosity and soil physical properties, and variability of large and small samples. In: Dairy farm soil management. (Eds P D Currie and R Loganathan) Occasional report No. 15. Fertilizer and Lime Research Centre, Massey University, Palmerston North. pp. 6178.

Evans, R. 1996. Some impacts of overgrazing by Reindeer in Finmark, Norway. Rangifer 16: 3-19.

Eyles, R.; Niyogi, D.; Weinstein, P.; Townsend, T.; Brooks, H.; Trott, A.; 2002. Ecosystem change and Campylobacter in freshwaters: a New Zealand perspective. In: Society for Applied Microbiology Summer Conference: Pathogens in the Environment and Changing Ecosystems. University of Nottingham, UK.

Loza, M. J. 2003. Reflection and visions in the deer industry. Proceedings of the New Zealand Society of Animal Production 63: 212-217.

McDowell, R. W.; Drewry, J. J.; Paton, R. J. 2004. Effects of deer and fence-line pacing on soil and water quality. Soil Use and Management 20: in press.

MfE. 1999. Recreational water quality guidelines. Ministry for the Environment, Wellington, 16pp.

Moyes, M. 2002. Venison into the $21^{\text {st }}$ century. The nutrition and management of deer on grazing systems. Grassland Research and Practice Series 9: 11-13.

Nguyen, M. L.; Sheath, G. W.; Smith, C. M.; Cooper, A. B. 1998. Impact of cattle treading on hill land. 2. Soil physical qualities and contaminant runoff. New Zealand Journal of Agricultural Research 41: 279290.

Pollard, J. C.; Drewry, J. 2002. Calving environments for farmed red deer: a review of current knowledge and a pilot study on soil quality. pp. 97-104. In: Proceedings of a Deer Course for Veterinarians, Deer Branch of the New Zealand Veterinary Association, Nelson.

Robertson, D. M.; Roerish, E. D. 1999. Influence of various water quality sampling strategies on load estimates for small streams. Water Resources Research 35: 3747-3759.

Thorrold, B.; Trolove, M. 1996. Erosion on deer farms 
in the Ngongotaha Valley. A report on field measurements and observations. AgResearch, Ruakura. 8 pp.

Vant, W. N. 2001. New challenges for the management of plant nutrients and pathogens in the Waikato River,
New Zealand. Water Science and Technology 43: 137144.

Wilcock, R. J. 1986. Agricultural runoff: a source of water pollution in New Zealand? New Zealand Agricultural Science 20: 98-103. 
